To cite this article: Olajumoke Bolanle Williams-llemobola, Adebowale Jeremy Adetayo, Mufutau Ayobami Asiru \& Jide Lawrence Ajayi (2021) Librarians' Emotional Intelligence and Conflict Management in Private University Libraries in South-West and South-South, Nigeria. Information Impact: Journal of Information and Knowledge Management, 12:1, 33-46, DOI: https://dx.doi.org/10.4314/iijikm.v12i1.3

To link to this article: https://dx.doi.org/10.4314/iijikm.v12i1.3

\title{
Librarians' Emotional Intelligence and Conflict Management in Private University Libraries in South-West and South-South, Nigeria
}

\author{
${ }^{1}$ Olajumoke Bolanle Williams-Ilemobola \\ ${ }^{2}$ Adebowale Jeremy Adetayo \\ ${ }^{3}$ Mufutau Ayobami Asiru \\ ${ }^{3}$ Jide Lawrence Ajayi \\ ${ }^{1}$ College of Law Library, Afe Babalola University, Ado-Ekiti, Nigeria \\ ${ }^{2}$ Department of Library and Information Science, Adeleke University Ede, Nigeria \\ ${ }^{3}$ Federal Polytechnic, Ado-Ekiti, Nigeria \\ ${ }^{3}$ Federal Polytechnic, Ado-Ekiti, Nigeria
}

\begin{abstract}
This study investigates the influence of librarians ${ }^{6}$ emotional intelligence on conflict management in private university libraries in South-West and South-South, Nigeria. The study adopted a survey research design. The population comprises 200 librarians in South-West and South-South, Nigeria. Total enumeration technique was used. A questionnaire was used for data collection. The instrument was tested for reliability, yielding Cronbach's alpha coefficients ranging from 0.87 to 0.95 . Descriptive \& inferential Statistics were used to analyse the data. The findings revealed that intrapersonal, interpersonal, intragroup, and intergroup conflicts as predominant in libraries. Collaborating, accommodating, sharing, avoidance and competing were prevalent techniques for managing conflicts in libraries. Librarians were found to be highly emotionally intelligent. The study concluded that librarians' emotional intelligence influenced conflict management. The study recommended that there is a need for private University Libraries to tackle misunderstandings among librarians while at the same time ensuring librarians are constantly emotionally intelligent.
\end{abstract}

Keywords Emotional Intelligence, Conflict Management, Private University, Libraries

CONTACT Olajumoke B. Williams-llemobola, Adebowale J. Adetayo, Mufutau A. Asiru and Jide L. Ajayiadebowale. adetayo@adelekeuniversity.edu.ng Department of Library and Information Science, Adeleke University Ede, Nigeria. 2021 The Authors Published with License by Information Impact 


\section{Introduction}

Conflict is defined as a dispute between parties or a scenario in which one party views another party as damaging its interests (Barmao, 2013), and it is increasingly seen as a two-edged sword (Carter \& Phillips, 2017). Conflicts in many organisations can be caused by various factors, including but not limited to structural factors such as employee specialisation, scarcity of resources, abuse of authority, and differing people's roles and expectations (Barmao, 2013). In addition, different perceptions, opinions, personalities, communication styles, values, backgrounds, interests, wants, needs, preferences, or goals, differing values, lack of trust and understanding, personality conflicts, hostility, opposing interests, poor communication, personal problems, and frustration are also causes of conflict (Kazimoto, 2013). Conflicts are unavoidable, and if they go unresolved, the repercussions may be damaging to librarians' performance and well-being, as well as the services provided by libraries. As a result, conflict management has become essential.

Conflict management is the process of preventing negative aspects of conflict while increasing positive aspects of conflict in a group or organisation. It aims to improve learning and group outcomes, which may include, but are not limited to, an organisation's efficacy or performance. Successful conflict management gives librarians the potential to improve decision-making, enhance innovation and library services, and create trust among librarians. As a result, correctly addressing conflicts would provide tremendous value to the library.

There are five types of conflict management techniques: integrating, compromising, avoiding, dominating, and obliging (Rahim, 2002). According to the contingency perspective of conflict, whether a conflict is productive or destructive is determined by the conflict management techniques used ( Chen, Zhao, Liu, \& Wu, 2012). Furthermore, the manner in which individuals handle or manage conflict, rather than the incidence of conflict, significantly impacts whether a conflict is functional or dysfunctional ( Chen, Liu, \& Tjosvold, 2005). Because of the necessity of successfully managing conflict, it has been concluded that knowing what impacts conflict is critical to building a synergy between the conflicting parties (Tuguz, Samra, \& Almallah, 2015).

Conflicts are not new phenomena in libraries; they are a part of what libraries regularly encounter due to the highly volatile and varied library environments. This frequently affects the services of libraries. As a result, librarians' capacity must be prepared with the tools to deal with variations in methods, perspectives, and frames of reference. One such tool that researchers routinely examine is emotional intelligence. This is because emotions are no longer regarded as separate entities that must be suppressed. Instead, they must be identified, managed, and incorporated into each individual's life in order for the individual to grow and fulfil their goals (Ashkanasy \& Dorris, 2017). Emotional intelligence (EI) emerged as an important psychological term different from general intelligence in the 1990s (O'Connor, Hill, Kaya, \& Martin, 2019). Goleman, Boyatzis and McKee later expanded the notion of emotional intelligence to include four domains: self-awareness, selfmanagement, social awareness, and relationship management (Goleman, Boyatzis, \& McKee, 2002). Furthermore, emotional intelligence is characterised as a collection of emotional and social competencies, as well as knowledge of other mental abilities. This concept was proposed by John Mayer, who emphasised humans' ability to manage their feelings and those of others, accept the perspectives of others, and govern social ties and feedback (Mafi \& Asefzade, 2014). Emotional intelligence aids a person to understand and manage their emotions, as well as use this knowledge to influence their thoughts and behaviour while engaging with others in the organisation and society as a whole. Emotionally intelligent people are better capable of managing themselves; thus, they are more likely to avoid engaging in conflict that might hurt their organisations (Ugwu, Enwereuzor, Fimber, \& Ugwu, 2017). According to Shaukat et al. (2017), a conflict between people results in resource loss. Chen et al. (2019) noted that individuals with greater degrees of emotional intelligence could better 
interpret, control, and utilise emotional information than those with lower levels. As a result, individuals' inclination to participate in conflict management in the face of stressful situations such as workplace disputes will vary (Ma \& Liu, 2019).

Librarians will be able to regulate their moods, emotions, and feelings if they understand their feelings. This will prevent them from going to extremes and may even affect their performance. It will also allow them to build empathy since when they understand the moods and feelings of others, they will be in a better position to work with them and prevent conflict. It is a well-known truth that librarians regularly interact with many types of library users with a wide range of moods and emotions. As a result, it is anticipated that every librarian will have some emotional intelligence capabilities that will allow them to address the library users' information demands appropriately.

To survive and compete effectively in today's volatile environment, organisations such as university libraries require librarians to be proactive, demonstrate initiative while performing their duties, and remain devoted to performing to high standards (Bakker \& Leiter, 2010). The work of librarians is one of service delivery, and daily, librarians give services to people of all backgrounds, cultures, feelings/emotions, talents, and personalities. Based on this, librarians must understand how to regulate emotions and provide excellent services to the "amazing" library users. While research on senior leadership teams provided a solid framework for further investigation of emotional intelligence in teams, library researchers and practitioners have yet to fully exploit this potential (Gola \& Martin, 2020). Similarly, information is scarce in the library literature about successful ways for developing emotional intelligence capabilities in the workplace. With the tremendous amount of diversity and cross-departmental work that exists in academic libraries today, it appears that there is a need to examine emotional intelligence as a means of conflict management. Despite the librarian's reputation for being amiable and willing to help their patron's quest for knowledge, disagreement frequently arises at university libraries. Often, librarians have diverse ways of resolving the disagreement. This makes it difficult for the library management to come up with a practical solution. As a result, the library administration is confronted with conflict management in order to resolve the problems that are impacting the proper operations of the library. Sometimes the library management strives to empathise with the demands of staff from various backgrounds that appear to be incomprehensible. Administrations will sometimes remain as neutral as possible in order to prevent controversy. Coping with and dealing with the various types of conflict situations is difficult. This is frequently due to differences in perceptions, opinions, personalities, communication styles, values, backgrounds, interests, wants, needs, preferences, and values among those affected by the conflict. As a result, a new approach to conflict management is required, which will be instrumental in tackling differing perspectives in conflict management. One such approach is emotional intelligence. Emotional intelligence has been presented as having the ability to bridge divides between people who have different beliefs. As a result, emotionally intelligent librarians may better handle disagreements. Given the above, this study seeks to investigate the influence of librarians' emotional intelligence on conflict management in private university libraries in South-West and South-South, Nigeria.

\section{Objective of the study}

The study's general objective is to investigate the influence of emotional intelligence on conflict management in private university libraries in South-West and South-South, Nigeria. This will be achieved under the following specific objectives, which are to:

1. examine the types of conflict that exist in the private university libraries in South-West and South-South Nigeria;

2. ascertain the techniques of managing conflict by librarians in private university libraries in South-West and South-South, Nigeria; 
3. ascertain the emotional intelligence of librarians in private university libraries in South-West and South-South, Nigeria.

\section{Hypothesis}

In order to achieve the objective of the study, the following null hypothesis was tested at 0.05 significant levels.

1. Librarians' emotional intelligence has no significant influence on conflict management in South-West and South-South, Nigeria.

\section{Methodology}

The study adopted a survey research design. The population for this study consist of all the librarians in 39 private universities in the South-West and South-South, Nigeria. This constitutes a total of 200 librarians. The population was totally enumerated because the population of the study is not too large. The research instrument used for this study is a structured questionnaire; it afforded the respondent some degree of privacy and enough time to reflect on the questions before responding. The questionnaire on conflict is self-developed, while emotional intelligence is adapted from the emotional intelligence scale (EIS) by Schutte et al.(1998). To guarantee that the instrument is consistently measuring what needs to be measured, it was submitted to reliability analysis to assess the questionnaire's reliability. A pretest was conducted on two private universities, Landmark University Omu-Aran (12) librarians and Al-Hikmah university Ilorin (8 librarians), which are not part of the study population. A total of 23 copies of the questionnaire are administered through a research assistant. Among the copies administered, only 20 copies are correctly completed and find useful. The reliability analysis for the questionnaire is displayed in table 1.

Table 1: Reliability statistics values of the major scales in the instrument

\begin{tabular}{llll}
\hline S/N & Variables & Numbers of Items & Cronbach's Alpha \\
\hline 1 & Types of conflict in university libraries (ICL) & 16 & 0.82 \\
3 & Techniques of Handling Conflict Scale (THCS) & 20 & 0.87 \\
5 & Emotional Intelligence Scale (EIS) & 20 & 0.95 \\
\hline
\end{tabular}

The questionnaire was administered to librarians in private universities in South-West and SouthSouth Nigeria. Data were coded and analysed using the statistical package for the social scientists (SPSS) software to develop descriptive and inferential statistics. Inferential statistics such as frequency, percentage counts, and mean scores were used for data analysis. In addition, simple regression was used for the hypothesis.

\section{Presentation of results}

The questionnaire was circulated among 200 librarians. A total of 163 filled-in questionnaires was collected, showing a response rate of $81.5 \%$. Therefore, the completely 163 copies of the questionnaire retrieved were used in the analysis of this study. 
Table 2: Demographic information of respondents

\begin{tabular}{|c|c|c|}
\hline $\begin{array}{l}\text { Demographics } \\
\text { Information }\end{array}$ & Frequency & Percentage \\
\hline \multicolumn{3}{|l|}{ Gender } \\
\hline Male & 75 & 46.0 \\
\hline Female & 88 & 54.0 \\
\hline Total & 163 & 100.0 \\
\hline \multicolumn{3}{|l|}{ Age Group } \\
\hline 20-30 years & 19 & 11.7 \\
\hline $31-40$ years & 53 & 32.5 \\
\hline $41-50$ years & 45 & 27.6 \\
\hline 51 and above & 40 & 24.5 \\
\hline No Response & 6 & 3.7 \\
\hline Total & 163 & 100 \\
\hline \multicolumn{3}{|l|}{ Rank } \\
\hline Library Officer & 29 & 17.8 \\
\hline Assistant Librarian & 32 & 19.6 \\
\hline Librarian II & 24 & 14.7 \\
\hline Librarian I & 35 & 21.5 \\
\hline Senior Librarian & 20 & 12.3 \\
\hline Principal Librarian & 8 & 4.9 \\
\hline Deputy University Librarian & 3 & 1.8 \\
\hline University Librarian & 9 & 5.5 \\
\hline No Response & 3 & 1.8 \\
\hline Total & 163 & 100 \\
\hline \multicolumn{3}{|l|}{ Academic Qualification } \\
\hline $\mathrm{BLS} / \mathrm{BSc}$ & 50 & 30.7 \\
\hline MLS/MLIS/MIRM & 87 & 53.4 \\
\hline PhD & 23 & 14.1 \\
\hline No Response & 3 & 1.8 \\
\hline Total & 163 & 100.0 \\
\hline
\end{tabular}


Findings in Table 2 demonstrate that most of the respondents were female $(54.0 \%)$ within the age bracket of 31-40 (32.5\%). Most are masters degree holders $(53.4 \%)$ within the rank of Lecturer 1 $(21.5 \%)$.

Table 3: Types of Conflicts that exist in Academic Libraries

\begin{tabular}{|c|c|c|}
\hline TYPES OF CONFLICT & Mean & S. D. \\
\hline \multicolumn{3}{|l|}{ INTRAPERSONAL CONFLICT } \\
\hline Conflict can arise due to lack of planning with oneself & 3.21 & .700 \\
\hline I normally have issues to resolve within myself & 2.72 & .905 \\
\hline Ordering around by supervisors causes conflict within oneself & 2.69 & .879 \\
\hline Too much responsibilities used to give me concern on how to solve them & 2.54 & .891 \\
\hline Grand Mean & 2.79 & \\
\hline \multicolumn{3}{|l|}{ INTERPERSONAL CONFLICT } \\
\hline Sometimes conflict arises between two people due to misunderstanding each other & 3.48 & .581 \\
\hline Individuals in the same level experience conflict among themselves & 3.27 & .658 \\
\hline Conflicts arise between people of different levels & 3.21 & .671 \\
\hline Conflicts arise between two people as a result of working together & 3.04 & .793 \\
\hline Grand Mean & 3.25 & \\
\hline \multicolumn{3}{|l|}{ INTRAGROUP CONFLICT } \\
\hline Conflicts arise among members of two groups & 3.06 & .678 \\
\hline Conflicts arise among members of a group & 3.05 & .710 \\
\hline Conflict can sometimes arise on members of a subgroup within a group & 3.04 & .637 \\
\hline Conflict arises among members of a group upon sharing resources & 3.04 & .793 \\
\hline Grand Mean & 3.05 & \\
\hline \multicolumn{3}{|l|}{ INTERGROUP CONFLICT } \\
\hline In the library, conflict can arise from different departments over-discharging their duties & 3.18 & .641 \\
\hline Conflict can arise between heads of different departments because of shift duty & 3.15 & .687 \\
\hline conflict can arise from different departments because of differences in perception & 3.15 & .660 \\
\hline Conflict can arise between librarian and lecturers & 3.09 & .665 \\
\hline Grand Mean & 3.14 & \\
\hline
\end{tabular}

The result presented in Table 3 shows that the types of conflict that exist in academic libraries are intrapersonal (mean=2.75), interpersonal (mean=3.25), intragroup (3.05), and intergroup 
(mean=3.14). However, interpersonal conflict was found to be the most prevalent, with a mean score of 3.25 .

Among the intrapersonal conflict among librarians, conflict arising due to lack of planning with oneself ranked highest (mean=3.21), which is followed by those with issues to resolve within themselves (mean=2.72), then being ordered around by supervisors (mean=2.69). The least cause of intrapersonal conflicts is too many responsibilities (mean=2.54). Regarding interpersonal conflicts among librarians, table 3 reveals misunderstanding between colleagues in the library ranked highest (mean=3.48), followed by individuals in the same level experiencing conflict among themselves (mean=3.27); then conflict arising between people of different levels (mean=3.21), while conflict arising between two people as a result of working together was the least (mean=3.04). Concerning intragroup conflict in libraries, the result shows a close tie for each factor. Conflict arising among members of two groups in the library was ranked highest (mean=3.06); followed closely by conflicts arising among members of a group in the library (mean=3.05), then conflict sometimes arising on members of subgroup in the library and conflict arising among members of a group upon sharing resources in the library both had a mean score of 3.04. Regarding intergroup conflicts, conflict arising from different departments over-discharging their duties was ranked the highest (mean=3.18), followed by conflict arising between heads of departments because of shift duty and conflicts arising from the different departments because of difference in perception, with both having a mean score of (mean=3.15), while conflict arising between library and lecturers was found to be the least $($ mean=3.09)

Table 4: Techniques of Managing Conflict in the Library

\begin{tabular}{|c|c|c|}
\hline Techniques of managing conflict & Mean & S.D \\
\hline \multicolumn{3}{|l|}{ COMPETING } \\
\hline Whenever it comes to defend myself, I am firm in the library & 2.93 & .733 \\
\hline I like to uphold my solutions to problems in the library & 2.71 & .829 \\
\hline I like to use my influence to win whenever there is conflict in the library & 2.55 & .924 \\
\hline I have a high concern for myself; therefore, I like to win in the library & 2.47 & .772 \\
\hline Grand Mean & 2.67 & \\
\hline \multicolumn{3}{|l|}{ COLLABORATING } \\
\hline $\begin{array}{l}\text { I am a decision-maker, but I make a point of listening to others to find the best solution } \\
\text { possible in the library }\end{array}$ & 3.47 & .591 \\
\hline $\begin{array}{l}\text { I explore issues with my colleagues to find solutions that meet everyone's needs in the } \\
\text { library }\end{array}$ & 3.44 & .629 \\
\hline $\begin{array}{l}\text { When a problem emerges, I am typically willing to shift my priorities in order to find a } \\
\text { solution. }\end{array}$ & 3.38 & .535 \\
\hline During conflict, I accept the recommendation of my colleagues in the library & 3.28 & .549 \\
\hline Grand Mean & 3.39 & \\
\hline \multicolumn{3}{|l|}{ ACCOMMODATING } \\
\hline When someone else feels they have an excellent proposal, I collaborate and aid them & 3.44 & 497 \\
\hline I try to adjust my priorities to accommodate other people's needs in the library & 3.41 & .530 \\
\hline $\begin{array}{l}\text { When conflict arises in the library, I make it a point of presenting my view, and I invite } \\
\text { others to do the same. }\end{array}$ & 3.34 & .549 \\
\hline I think it is more important to get along than to win an argument in the library & 3.28 & .714 \\
\hline Grand Mean & 3.37 & \\
\hline \multicolumn{3}{|l|}{ SHARING } \\
\hline I like things to be done in such a way everyone will be satisfied in the library & 3.26 & .644 \\
\hline $\begin{array}{l}\text { I try to negotiate and adopt a "give-and-take" approach to problem situations in my unit in } \\
\text { the library }\end{array}$ & 3.18 & .719 \\
\hline I try to reach compromise through negotiation in the library & 3.08 & .694 \\
\hline I prefer to compromise when solving problems and just move on in the library & 2.73 & .854 \\
\hline Grand Mean & 3.06 & \\
\hline AVOIDANCE & & \\
\hline
\end{tabular}




\begin{tabular}{|l|l|l|}
\hline I sometimes avoid taking positions that would create controversy in the library & 2.90 & .798 \\
\hline $\begin{array}{l}\text { Differences of opinion are not always worth worrying about, so I usually avoid them in the } \\
\text { library }\end{array}$ & 2.73 & .809 \\
\hline I usually try to avoid trouble by keeping quiet in the library & 2.66 & .912 \\
\hline I avoid hard feelings by keeping my disagreements with others to myself in the library & 2.64 & .792 \\
\hline Grand Mean & $\mathbf{2 . 7 3}$ & \\
\hline
\end{tabular}

Results showed that collaborating (mean=3.39) was the most prevalent technique for managing conflicts. This is followed closely by accommodating (mean=3.37), then by sharing (mean=3.06) and avoidance (mean=2.73). The least prevalent technique for managing conflict is competing (mean=2.67). In terms of individual techniques under each category, listening to others to find the best solution possible in the library had the highest mean score of 3.47. This is followed closely by exploring issues with colleagues to find solutions that meet everyone's needs, cooperate with those with good proposals, and aiding them, both having a mean score of 3.44. Furthermore, having a high concern for oneself (mean=2.47) was not a technique for managing conflicts in the library.

Table 5: Emotional Intelligence of Librarians

\begin{tabular}{|c|c|c|c|c|c|c|}
\hline $\begin{array}{c}\text { Emotional } \\
\text { intelligence of librarians }\end{array}$ & $\begin{array}{l}\text { Strongly } \\
\text { Agree }\end{array}$ & Agree & Disagree & $\begin{array}{l}\text { Strongly } \\
\text { Disagree }\end{array}$ & Mean & S.D \\
\hline \multicolumn{7}{|l|}{ SELF-AWARENESS } \\
\hline $\begin{array}{l}\text { I am capable of withstanding } \\
\text { pressure in my library }\end{array}$ & $56(34.4)$ & $101(62.0)$ & $6(3.7)$ & - & 3.31 & .537 \\
\hline $\begin{array}{l}\text { When I am faced with an obstacle; } \\
\text { I remember the time I face a } \\
\text { similar obstacle and overcome } \\
\text { them in my library }\end{array}$ & $55(33.7)$ & $100(61.3)$ & $7(4.3)$ & $1(.6)$ & 3.28 & .572 \\
\hline $\begin{array}{l}\text { Major events in my life have led } \\
\text { me to know what is important and } \\
\text { what is not important in my library }\end{array}$ & $50(30.7)$ & $105(64.4)$ & $8(4.9)$ & - & 3.26 & .540 \\
\hline $\begin{array}{l}\text { I am aware of my emotions as I } \\
\text { experience them in my library }\end{array}$ & $50(30.7)$ & $101(62.0)$ & $11(6.7)$ & $1(.6)$ & 3.23 & .591 \\
\hline $\begin{array}{l}\text { I perceive fresh opportunities as } \\
\text { my mood changes }\end{array}$ & $30(18.4)$ & $113(69.3)$ & $19(11.7)$ & $1(.6)$ & 3.06 & .569 \\
\hline Grand Mean & & & & & 3.23 & \\
\hline \multicolumn{7}{|l|}{ SOCIAL AWARENESS } \\
\hline $\begin{array}{l}\text { I congratulate others on doing } \\
\text { something good }\end{array}$ & $70(42.9)$ & $92(56.4)$ & $1(.6)$ & - & 3.42 & .508 \\
\hline $\begin{array}{l}\text { I always try to inspire confidence in } \\
\text { others in my library }\end{array}$ & $61(37.4)$ & $100(61.3)$ & $2(1.2)$ & & 3.36 & .507 \\
\hline $\begin{array}{l}\text { I am optimistic and encouraged by } \\
\text { the bright side of life in my library }\end{array}$ & $47(28.8)$ & $110(67.5)$ & $5(3.1)$ & $1(.6)$ & 3.25 & .534 \\
\hline $\begin{array}{l}\text { I am able to identify my emotions } \\
\text { as they occur to me }\end{array}$ & $39(23.9)$ & $111(68.1)$ & $12(7.4)$ & $1(.6)$ & 3.15 & .562 \\
\hline
\end{tabular}




\begin{tabular}{|c|c|c|c|c|c|c|}
\hline $\begin{array}{l}\text { I enjoy sharing my feelings with } \\
\text { people }\end{array}$ & $47(28.8)$ & $91(55.8)$ & $23(14.1)$ & $2(1.2)$ & 3.12 & .683 \\
\hline Grand Mean & & & & & 3.26 & \\
\hline \multicolumn{7}{|l|}{ SELF MANAGEMENT } \\
\hline $\begin{array}{l}\text { portray myself in a way that } \\
\text { produces a favourable impression } \\
\text { on people. }\end{array}$ & $62(38.0)$ & $98(60.1)$ & $2(1.2)$ & $1(.6)$ & 3.36 & .541 \\
\hline $\begin{array}{l}\text { When I experience positive } \\
\text { emotions, I know how to make } \\
\text { them last in my library }\end{array}$ & $55(33.7)$ & $104(63.8)$ & $4(2.5)$ & - & 3.31 & .515 \\
\hline $\begin{array}{l}\text { I have control over my emotions in } \\
\text { my library }\end{array}$ & $58(35.6)$ & $94(57.7)$ & $10(6.1)$ & $1(.6)$ & 3.28 & .604 \\
\hline $\begin{array}{l}\text { I am unlikely to give away during } \\
\text { crisis or adversity in my library }\end{array}$ & $31(19.0)$ & $94(57.7)$ & $30(18.4)$ & $8(4.9)$ & 2.91 & .752 \\
\hline $\begin{array}{l}\text { can easily give up when } \\
\text { challenges arise in my library }\end{array}$ & $17(10.4)$ & $44(27.0)$ & $63(38.7)$ & $39(23.9)$ & 2.24 & .935 \\
\hline Grand Mean & & & & & 3.02 & \\
\hline \multicolumn{7}{|l|}{ RELATIONSHIP MANAGEMENT } \\
\hline $\begin{array}{l}\text { I am cheerful and approachable in } \\
\text { my library }\end{array}$ & $90(55.2)$ & $72(44.2$ & $1(.6)$ & $-76(46.6)$ & 3.55 & .512 \\
\hline $\begin{array}{l}\text { I try to understand individual and } \\
\text { group differences in my library }\end{array}$ & $76(46.6)$ & $87(53.4)$ & - & - & 3.47 & .500 \\
\hline $\begin{array}{l}\text { I handle difficult people at work } \\
\text { with diplomacy in my library }\end{array}$ & $64(39.3)$ & $98(60.1)$ & $1(.6)$ & - & 3.39 & .501 \\
\hline $\begin{array}{l}\text { am aware of non-verbal } \\
\text { messages other people send my } \\
\text { library }\end{array}$ & $48(29.4)$ & $99(60.7)$ & $14(8.6)$ & $2(1.2)$ & 3.18 & .631 \\
\hline $\begin{array}{l}\text { I am aware of the non-verbal } \\
\text { message I send to others in my } \\
\text { library }\end{array}$ & $45(27.6)$ & $101(62.0)$ & $13(8.0)$ & $4(2.5)$ & 3.15 & .660 \\
\hline Grand Mean & & & & & 3.35 & \\
\hline
\end{tabular}

Table 5 describes the emotional intelligence of librarians in university libraries in south-south and south-west Nigeria. It was found out that librarians were emotionally intelligent. Furthermore, they were found to portray a high level of relationship management with a mean score of 3.35, followed by social awareness (mean=3.26), then self-awareness (mean=3.23). Although self-management was the least among the emotional intelligence indicators studied, librarians were found to have a good level of self-management with a mean score of 3.02 .

Under self-awareness as an indicator for emotional intelligence, librarians were highly capable of withstanding pressure in the library (mean=3.31); likewise, when faced with obstacles, they remember the time they faced similar obstacles and overcome obstacles in the library (mean=3.28).In the same vein, librarians agreed that major events in their life had led them to know what is important and what 
is not important in the library (mean=3.26). They were also aware of their emotions as they experience them in my library (mean=3.23). Finally, they perceive fresh opportunities as their mood changes (mean=3.23).

The next indicator of emotional intelligence is social awareness. The result shows that librarians congratulate others on doing something good (mean=3.42). Furthermore, they always inspire confidence in others in their library (mean=3.36); they are optimistic and encourage by the bright side of life in the library (mean=3.25). In addition, they are able to identify their emotions as they occur to them. (mean=3.15), and they enjoy sharing their feelings with people (mean=3.12).

The result in table 5 equally shows the responses for self-management items for emotional intelligence. The result shows that librarians portray themselves in a way that produces a favourable impression on people (mean=3.36); when they experience positive emotions, they know how to make them last in the library (mean=3.31). They control their emotions (mean=3.28) and are unlikely to give away during crisis or adversity in the library (mean=2.91). However, the item "they do not easily give up when challenges arise in the library" had a mean score of 2.24 , which indicates that librarians are likely to give up when challenges arise in the library

Relationship management is an indicator in the emotional intelligence scale, as seen in table 6 . The result shows that librarians are cheerful and approachable in the library (mean=3.55). Moreover, they try to understand individual and group differences in their library (mean=3.47).In the same vein, the result shows that they handle people at work with diplomacy in the library (mean=3.39). In addition, they are aware of non-verbal messages other people send in the library (mean=3.18) and are aware of the non-verbal messages they send to others in the library (mean=3.15).

Table 6: Influence of emotional intelligence on conflict management

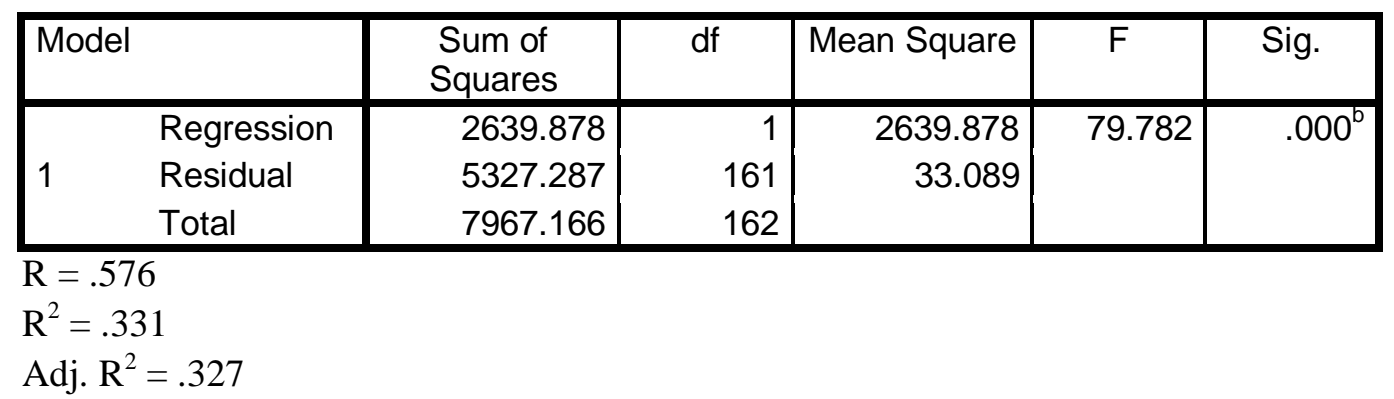

The result in table 6 reveals that there is a significant influence of librarians' emotional intelligence on conflict management $\left[\mathrm{F}(1,161)=79.410 ; \mathrm{R}=.576, \mathrm{R}^{2}=.331\right.$, Adj. $\left.\mathrm{R}^{2}=.327, \mathrm{P}<.05\right]$.

Table 6 shows the result of simple regression carried out on librarians' emotional intelligence on conflict management. The R, i.e. the correlation coefficient, is 0.576 , which indicates a moderate but positive relationship between librarians' emotional intelligence on conflict management. Therefore, the strength of the relationship between the dependent and independent variable is $57.6 \%$.

The $\mathrm{R}$ square of 0.331 shows that by $33.1 \%$ the effect librarians' emotional intelligence on conflict management. Simply put, one can say that there were other predictors (factors) that influence conflict management. However, librarians' emotional intelligence accounts for $33.1 \%$ effect on conflict management. $\mathbf{P}\left(.000^{\mathrm{b}}\right)$ value is lesser than 0.05 significant level. Therefore, the null hypothesis is rejected, while the alternate hypothesis is accepted. Which state that librarians' emotional intelligence has no significant influence on conflict management in South-West and South-South, Nigeria. 


\section{Discussion}

The study's findings indicate that several sorts of conflicts exist in the library. This is reinforced by Danielsson et al. (2015), who stated that among thousands of participants in their research over the last two years, 84 percent had reported being in some form of conflict scenario with their coworkers, with around 50 percent experiencing it weekly. Furthermore, interpersonal conflict was found to be the most prevalent. This corroborates Tremmel Sonnentag and Casper (2019) findings, who discovered that interpersonal conflict is common in the workplace. This was also supported by Yang, Trincado and Labianca (2019), who found interpersonal conflict as a prevalent issue among workers. Results showed that collaborating was the most prevalent technique for managing conflicts. This is followed closely by accommodating, then by sharing, avoidance and competing. This partially agrees with the findings of Mallappa and Kumar (2015), which emphasises the need for techniques to manage conflicts in the library, such as negotiation and convincing. Similarly, Krautter (2014) also advocated conflicts management techniques in a paper titled "Advocating for the devil: Transforming conflict in libraries".

The result revealed a high level of emotional intelligence among librarians working in private university libraries. These findings imply that librarians in the private university libraries in SouthWest and South-South Nigeria are emotionally intelligent and possess the abilities indicated in this study for each component of emotional intelligence. It demonstrates that these librarians understand their feelings as well as the feelings of library users. Furthermore, it indicates that these librarians recognise the need for high emotional intelligence in conflict resolution. This supports the findings of Khan and Ullah (2014), who discovered that librarians had a high degree of emotional intelligence. Each dimension of emotional intelligence, such as relationship management, social awareness, selfawareness, and self-management, was found to be high among librarians. This partially corroborates the findings of Henry et al.(2018), who found empathy, self-awareness, self-motivation, selfmanagement, and social skills to be the emotional intelligence strength of librarians.

The study revealed that emotional intelligence significantly influences the conflict management of librarians. This is consistent with earlier research indicating that high emotional intelligence is required for library leaders and managers (Crumpton, 2015). This is corroborated by Somera (2019), who found that the level of emotional intelligence significantly affected the level of conflict resolution of academic workers. Likewise, Bibi, Karim, and Din (2013) found emotional intelligence to reduce the impact of "abuse, production deviance, sabotage, theft, and withdrawal" among academic faculty.

\section{Conclusion}

The study concludes by noting that emotional intelligence significantly influences conflict management of librarians in South-West and South-South, Nigeria. The significance of emotional intelligence cannot be overstated since it is characterised as a collection of emotional and social competencies and knowledge of other mental abilities. As found in the study, these abilities were discovered to be on a high level among librarians. They are essential in dealing with the various conflicts in highly volatile and varied library environments. Although competing was found to be the least prevalent technique in managing conflicts among the respondents, collaborating was found to be the most prevalent technique for managing conflicts in university libraries. The findings also showed the importance of accommodating, sharing, and avoidance in dealing with conflicts in private university libraries in South-West and South-South Nigeria. The study suggests that the management of private university libraries tackle misunderstandings among librarians. This will reduce the occurrence of conflicts in the library. Library management must also ensure that they provide training for librarians on conflict management. This training should be directed towards sustaining the high level of emotional intelligence of librarians. 


\section{References}

Ashkanasy, N. M., \& Dorris, A. D. (2017). Emotions in the Workplace. Annual Review of Organizational Psychology and Organizational Behavior, 4, 67-90. https://doi.org/10.1146/annurev-orgpsych-032516-113231

Bakker, A. B., \& Leiter, M. P. (2010). Where to go from here: Integration and future research on work engagement. In Work engagement: A handbook of essential theory and research (pp. 181196). Psychology Press. Retrieved from https://psycnet.apa.org/record/2010-06187-013

Barmao, C. (2013). Conflict: Challenges and Mechanisms Head Teachers can use to Manage conflict towards an improvement Teacher Morale in Public Primary Schools in Eldoret Municipality, Kenya. Journal of Social Science for Policy Implications, 1(1), 14-22. Retrieved from http://jsspi.com/vol-1-no-1-june-2013-abstract-2-jsspi

Bibi, Z., Karim, J., \& Din, S. (2013). Workplace incivility and counterproductive work behavior: Moderating role of emotional intelligence. Pakistan Journal of Psychological Research, 317334. Retrieved from http://www.pjprnip.edu.pk/pjpr/index.php/pjpr/article/download/309/307

Carter, A. B., \& Phillips, K. W. (2017). The double-edged sword of diversity: Toward a dual pathway model. Social and Personality Psychology Compass, 11(5), e12313. https://doi.org/10.1111/spc3.12313

Chen, G., Liu, C., \& Tjosvold, D. (2005). Conflict management for effective top management teams and innovation in China. Journal of Management Studies, 42(2), 277-300. https://doi.org/10.1111/j.1467-6486.2005.00497.x

Chen, X. H., Zhao, K., Liu, X., \& Wu, D. D. (2012). Improving employees' job satisfaction and innovation performance using conflict management. International Journal of Conflict Management, 23(2), 151-172. https://doi.org/10.1108/10444061211218276

Crumpton, M. A. (2015). The emotionally intelligent mentor. Advances in Library Administration and Organization, 34, 29-57. https://doi.org/10.1108/S0732-067120150000034002

Danielsson, C. B., Bodin, L., Wulff, C., \& Theorell, T. (2015). The relation between office type and workplace conflict: A gender and noise perspective. Journal of Environmental Psychology, 42, 161-171. https://doi.org/10.1016/j.jenvp.2015.04.004

Gola, C. H., \& Martin, L. (2020). Creating an Emotional Intelligence Community of Practice: A Case Study for Academic Libraries. Journal of Library Administration, 60(7), 752-761. https://doi.org/10.1080/01930826.2020.1786982

Goleman, D., Boyatzis, R., \& McKee, A. (2002). Primal leadership: Learning to lead with emotional intelligence (1st ed.). Harvard Business Review Press.

Henry, J., Eshleman, J., Croxton, R., \& Moniz, R. (2018). Incivility and Dysfunction in the Library Workplace: Perceptions and Feedback from the Field. Journal of Library Administration, 58(2), 128-152. https://doi.org/10.1080/01930826.2017.1412708

Kazimoto, P. (2013). Analysis of conflict management and leadership for organisational change. International Journal of Research in Social Sciences, 3(1), 16-25. Retrieved from http://www.ijsk.org/uploads/3/1/1/7/3117743/2_conflict_management.pdf

Khan, A., \& Ullah, I. (2014). Emotional intelligence of library professional in Pakistan: A descriptive analysis. PUTAJ-Humanities and Social Sciences, 21(2), 89-96. Retrieved from https://www.academia.edu/download/37314141/EI_PUTAJ_2014.pdf

Krautter, M. R. (2014). Advocating for the Devil: Transforming Conflict in Libraries. Imagine, Innovate, Inspire: Proceedings of the ACRL 2013 Conference, 9-15. Chicago, IL: Association of College and Research Libraries. Retrieved from http://libres.uncg.edu/ir/uncg/f/M_Krautter_Advocating_2013.pdf 
Ma, J., \& Liu, C. (2019). The moderating effect of emotional intelligence on the relationship between supervisor conflict and employees' counterproductive work behaviors. International Journal of Conflict Management, 30(2), 227-245. https://doi.org/10.1108/IJCMA-11-2017-0140

Mafi, L., \& Asefzade, S. (2014). Association of emotional intelligence and communication skills with patients in nurses. Journal of Inflammatory Diseases, 18(374), 34-40. Retrieved from https://www.sid.ir/en/journal/ViewPaper.aspx?id=399669

Mallappa, V., \& Manoj Kumar, K. S. (2015). Conflict management in management library professionals. DESIDOC Journal of Library and Information Technology, 35(3), 200-206. https://doi.org/10.14429/djlit.35.3.8209

O’Connor, P. J., Hill, A., Kaya, M., \& Martin, B. (2019). The measurement of emotional intelligence: A critical review of the literature and recommendations for researchers and practitioners. Frontiers in Psychology, 10(MAY), 1116. https://doi.org/10.3389/fpsyg.2019.01116

Rahim, M. A. (2002). Toward a theory of managing organisational conflict. International Journal of Conflict Management, 13(3), 206-235. https://doi.org/10.1108/eb022874

Schutte, N. S., Malouff, J. M., Hall, L. E., Haggerty, D. J., Cooper, J. T., Golden, C. J., \& Dornheim, L. (1998). Development and validation of a measure of emotional intelligence. Personality and Individual Differences, 25(2), 167-177. https://doi.org/10.1016/S0191-8869(98)00001-4

Shaukat, R., Yousaf, A., \& Sanders, K. (2017). Examining the linkages between relationship conflict, performance and turnover intentions: Role of job burnout as a mediator. International Journal of Conflict Management, 28(1), 4-23. https://doi.org/10.1108/IJCMA-08-2015-0051

Somera, J. D. (2019). Emotional intelligence and conflict resolution approaches of multigenerational teachers of trinity university of Asia. In researchgate.net. Philippines. https://doi.org/10.13140/RG.2.2.23344.07689

Tremmel, S., Sonnentag, S., \& Casper, A. (2019). How was work today? Interpersonal work experiences, work-related conversations during after-work hours, and daily affect. Work and Stress, 33(3), 247-267. https://doi.org/10.1080/02678373.2018.1496158

Tuguz, K., Samra, R. A., \& Almallah, I. (2015). An exploratory study of the impact of cultural intelligence on conflict management styles: Evidence from Jordan. Middle East Journal of Business, 55(2433), 1-16. Retrieved from http://www.mejb.com/upgrade_flash/August2015/Conflict.pdf

Ugwu, L. I., Enwereuzor, I. K., Fimber, U. S., \& Ugwu, D. I. (2017). Nurses’ burnout and counterproductive work behavior in a Nigerian sample: The moderating role of emotional intelligence. International Journal of Africa Nursing Sciences, 7, 106-113. https://doi.org/10.1016/j.ijans.2017.11.004

Yang, S. W., Trincado, F., Labianca, G. (Joe), \& Agneessens, F. (2019). Negative Ties at Work. In Social Networks at Work (pp. 49-78). Routledge. https://doi.org/10.4324/9780203701942-4

\begin{abstract}
About the Authors
Williams-Ilemobola Olajumoke is currently the Librarian, College of Law Library, Afe Babalola University Ado Ekiti, Nigeria. She has put to bear three decades of cumulative experience as a law librarian, academic, researcher and an enterprenuer. Her librarianship background and the Diploma in Law, adds to her diverse multidisciplinary profile. This presents her with a unique perspective on the compilation of Legal materials and expert with classification and cataloguing of Legal information materials. Her focus has been on Human Development, Librarianship \& Information Dissemination related issues, Library Automation and ICT. She was a Librarian at Faculty of Law, Lead City University, Ibadan for three years before joining Abuad. She is actively involved in training students
\end{abstract}


at the undergraduate with Use of Library and Study Skills (GST 115), as well serve as a Reference Librarian, involved in disseminating information to the library users. She is a passionate teacher and educationist with a devoted concern for the protection of children. She is a versatile administrator having occupied leadership positions of College Librarian, Afe Babalola University; Faculty Librarian Lead City University, Ibadan, Volunteer Librarian, Association for Reproductive and Family Health, Oyo State and an Assistant Librarian, Kogi State University, Lokoja.

Adetayo, Adebowale Jeremy is an academic staff of Adeleke University. His research interest is Library Science, Social media, Knowledge Management, and Business Information Management. He has published many articles in reputable journals and currently working on projects relating to pandemics, vaccines and virtual learning. He is a graduate of Babcock University.

Asiru, Ayobami Mufutau is a professional teacher, a journalist and a librarian. He obtained NCE in Ikere Ekiti, Diploma in Journalism at I I J Abuja, BA ed Ado Ekiti and Master in Library and Information Studies in Ibadan. He is presently a principal Librarian in The Federal Polytechnic Ado Ekiti. He has published many articles in reputable journals and currently carrying out research on how library information resources can assist inmates for recidivism- reduction.

Ajayi, Jide Lawrence is a currently a Principal Librarian at the Polytechnic Digital Library of the Federal Polytechnic Ado-Ekiti. 